\title{
A treatment with a boiled aqueous extract of Hancornia speciosa Gomes leaves improves the metabolic status of streptozotocin-induced diabetic rats
}

\author{
Leila S. Neto', Rafaianne Q. Moraes-Souza ${ }^{1,2}$, Thaigra S. Soares ${ }^{1,2}$, Marcelo S. Pinheiro', Thaís Leal-Silva', \\ Juliana C. Hoffmann ${ }^{1}$, Madileine F. Américo ${ }^{1}$, Kleber E. Campos', Débora C. Damasceno ${ }^{2}$ and Gustavo T. Volpato ${ }^{1,2^{*}}$
}

\begin{abstract}
Background: Hancornia speciosa is usually used in Brazilian folk medicine to treat diabetes. The hypothesis of the present study is that this medicinal plant exerts beneficial effects on hyperglycemia, preventing diabetic complications. Therefore, the aim of this study was to evaluate the treatment effect of the aqueous extract of $H$. speciosa leaves on metabolic parameters of diabetic rats.

Methods: The H. speciosa extract $(400 \mathrm{mg} / \mathrm{Kg}$ ) was administered to both nondiabetic and severely diabetic female Wistar rats by gavage. The Oral Glucose Tolerance Test was performed and the area under the curve (AUC) was estimated on day 17 of pregnancy. After 21 days of treatment, the animals were anesthetized and killed to obtain organ weights. Blood samples were collected for an analysis of serum biochemical parameters.

Results: After treatment with the H. speciosa extract, the parameters of nondiabetic rats remained unchanged. In treated diabetic rats, glycemia, AUC, dyslipidemia parameters, and relative organ weights were decreased compared with nontreated diabetic rats. Severely diabetic rats showed decompensated hyperglycemia, polydipsia, hyperphagia and dyslipidemia. However, the aqueous extract of $H$. speciosa leaves decreased diabetes complications (indicating a lack of toxicity), reduced blood glucose levels, and exerced lipid-lowering effects.
\end{abstract}

Conclusion: Based on or findings, the $\mathrm{H}$. speciosa leaf extract may be a safe and promising candidate treatment for diabetes and other diseases.

Keywords: Hancornia speciosa, Diabetes, Medicinal plants, Biochemical, Rats

\section{Background}

Medicinal plants have positively affected human health. These plants are consumed mostly based on personal experience or traditional knowledge [1]. In the last two decades, the use of alternative and complementary

\footnotetext{
* Correspondence: gtvolpato@gmail.com

${ }^{1}$ Laboratory of System Physiology and Reproductive Toxicology, Institute of Biological and Health Sciences, Federal University of Mato Grosso (UFMT), Av. Valdon Varjão 6390, Barra do Garças, Mato Grosso State 78600-000, Brazil ${ }^{2}$ Laboratory of Experimental Research on Gynecology and Obstetrics, Botucatu Medical School, Univ Estadual Paulista_Unesp, Distrito de Rubião Júnior s/n, Botucatu, São Paulo State 18618-687, Brazil
}

medicine has considerably increased worldwide [2] because herbal medicine is considered an innate part of the culture that has been used and disseminated over the generations [3].

One plant widely used in folk medicine is Hancornia speciosa Gomes (family Apocynaceae), known as mangaba. Mangaba is a native Brazilian tree, and Gomes described the fruitful species in 1812. This tree thrives in a dry tropical and subtropical climate, and it has been found in several regions of Brazil. H. speciosa is tolerant to periods of drought and higher temperatures, and presents a good vegetative development [4]. Previous

C The Author(s). 2020 Open Access This article is licensed under a Creative Commons Attribution 4.0 International License, which permits use, sharing, adaptation, distribution and reproduction in any medium or format, as long as you give appropriate credit to the original author(s) and the source, provide a link to the Creative Commons licence, and indicate if changes were made. The images or other third party material in this article are included in the article's Creative Commons licence, unless indicated otherwise in a credit line to the material. If material is not included in the article's Creative Commons licence and your intended use is not permitted by statutory regulation or exceeds the permitted use, you will need to obtain permission directly from the copyright holder. To view a copy of this licence, visit http://creativecommons.org/licenses/by/4.0/ The Creative Commons Public Domain Dedication waiver (http://creativecommons.org/publicdomain/zero/1.0/) applies to the data made available in this article, unless otherwise stated in a credit line to the data. 
phytochemical studies identified different classes of $H$. speciosa leaf constituents, including cyclitols, cinnamic acids, flavonoids, steroids, triterpenes and phenolic compounds [4-6].

In folk medicine, this plant is used as a treatment for several diseases such tuberculosis, lower back pain, hypertension, dysmenorrhea, respiratory and venereal diseases, dermatosis and ulcers, obesity, and Diabetes mellitus [7, 8]. H. speciosa exerts vasodilatory $[9,10]$, cancer chemopreventive $[5,11]$, and antihypertensive effects $[7,12]$, and stimulates the migration and/or proliferation of fibroblasts [13]. From a scientific perspective, a specific study designed to investigate the plant safety and efficacy is necessary by developing simple bioassays for biological standardization, pharmacological and toxicological evaluation, and by developing animal models [14]. Only one study has evaluated the hypoglycemic effect of $H$. speciosa leaves. According to Pereira et al. [15], a single dose of the $H$. speciosa leaves $(300 \mathrm{mg} / \mathrm{kg}$ of ethanolic extract) reduced blood glucose level in male Swiss mice, inhibiting intestinal $\alpha$-glucosidase activity in vitro and stimulating glucose uptake in adipocytes. However, this study was not performed on an animal model of diabetes. Thus, the hypothesis of the present study is that this medicinal plant exerts beneficial effects on hyperglycemia, preventing diabetic complications. Therefore, the aim of this study was evaluate the treatment effect of the aqueous extract of $H$. speciosa leaves on metabolic parameters of diabetic rats.

\section{Methods}

\section{Extraction of plant materials}

The Hancornia speciosa leaves were collected from Pontal do Araguaia, Mato Grosso State, Brazil $\left(15^{\circ} 91^{\prime}\right.$ 51" S and 52 27 $\left.62^{\prime \prime} \mathrm{W}\right)$, between April and May 2014 in the morning. The plant was identified and authenticated by Prof. Maryland Sanchez Lacerda Pedroni from the Botanical Department of Mato Grosso Federal University (UFMT), where a voucher specimen (UFMT 02285) has been deposited. The plant leaves were dried at $50{ }^{\circ} \mathrm{C}$ for a $24 \mathrm{~h}$ period in an aerated stove, ground and a powder was prepared, similar to the method used to prepare the folk medicine. The $H$. speciosa aqueous extract was prepared by boiling one liter (L) of water containing $60 \mathrm{~g}(\mathrm{~g})$ of the powdered plant leaves for 5 min (min). The extract was agitated and covered until it reached room temperature. The residue was removed by filtration (1 mm pore size filter) and the extract was then suitably concentrated in a rotary evaporator. A sample was separated to determination the concentration of the solid component, and the extract was divided into aliquots stored at $-20{ }^{\circ} \mathrm{C}$ until further use.

\section{Animals}

Female Wistar rats (190-210 g) were obtained from the UFMT Vivarium and were maintained under standard laboratory conditions $\left(22 \pm 3{ }^{\circ} \mathrm{C}, 12\right.$-h light/dark cycle), with pelleted food (Purina ${ }^{\circ}$ rat chow, São Paulo, Brazil) and tap water provided ad libitum. The procedures and animal handling protocols were authorized by the Ethics Committee for Animal Research of the UFMT, Brazil (Protocol number 23108.001991/13-1).

After 2 weeks of acclimation, diabetes was induced by injecting streptozotocin (STZ, Sigma Chemical Company ${ }^{\circ}$, St. Louis, MO) into fasting rats. STZ was intravenously (i.v.) injected at a dose of $40 \mathrm{mg} / \mathrm{kg}$ after it was dissolved in citrate buffer $(0.1 \mathrm{M}, \mathrm{pH} 6.5)$. Non-diabetic (control) rats received and i.v. injection of citrate buffer. Blood glucose concentrations were measured by conventional glucometer 7 days after diabetes induction; glucose concentrations exceeding $300 \mathrm{mg} / \mathrm{dL}$ confirmed the diabetic state, and these rats were included in the diabetic group [16].

\section{Experimental groups and treatment}

After confirming the successful establishment of the diabetes model, the rats were divided into four experimental groups ( $n=11$ animals/group): Control - rats treated with vehicle (water); Treated Control - rats treated with the H. speciosa extract; Diabetic - diabetic rats treated with vehicle, and Treated Diabetic - diabetic rats treated with the $H$. speciosa extract. The $H$. speciosa extract was administered at a dose of $400 \mathrm{mg} / \mathrm{kg} /$ day by oral gavage for 21 days. Body weight, water intake, food intake and blood glucose levels were also evaluated weekly in the morning. The animals were not fasted.

\section{Oral glucose tolerance test}

The oral glucose tolerance test (OGTT) was performed on day 17 of treatment to evaluate the development of inadequate glucose metabolism. OGTT is regularly used to determine a clinical diagnosis of diabetes. After an overnight fast of $8 \mathrm{~h}$, blood was collected from the tail of the rats by venipuncture to determine the glycemic status (time point 0 ). Afterwards, the treated groups received the plant extract and the control group received vehicle according to the method described by Chayarop et al. [17]. After $30 \mathrm{~min}$, a glucose solution $(200 \mathrm{~g} / \mathrm{L})$ was prepared at a final dose of $2 \mathrm{~g} / \mathrm{kg}$ body weight and was intragastrically administered to rats. Next, blood glucose concentrations were measured at 30,60 and $120 \mathrm{~min}$ $[18,19]$. Glucose concentrations in blood collected from the tail vein were measured using a conventional glucometer. Glucose responses during the OGTT were evaluated by estimating the total area under the curve (AUC) using the trapezoidal method [20]. 


\section{Data collection}

After 21 days of treatment, the non-fasted rats were anesthetized with an injection of sodium pentobarbital (Thiopentax $^{\odot}$ - $120 \mathrm{mg} / \mathrm{kg}$ ) and blood samples were collected after decapitation for and analysis of biochemical biomarkers. Moreover, the heart, liver, spleen, and kidneys were removed and weighed. The relative weight was determined by calculating the ratio of the weight of each organ (grams) to the body weight on day 21 of pregnancy minus the gravid uterus weight (grams) $\times 100$. The result was reported in grams $/ 100 \mathrm{~g}$ body weight.

The blood samples were collected in anticoagulant-free test tubes, incubated on in ice for $30 \mathrm{~min}$ and then centrifuged at $1300 \times g$ for $10 \mathrm{~min}$ at $4{ }^{\circ} \mathrm{C}$. The supernatant was collected as the serum fraction and stored at $-80^{\circ} \mathrm{C}$ until a further analysis of the biochemical parameters. Serum concentrations of total protein were determined using a colorimetric method with the Biuret reagent [21]. The total cholesterol, triglyceride, and high-density lipoprotein (HDL-c) concentrations, as well as alanine aminotransferase (ALT), and aspartate aminotransferase (AST) activities were estimated using an enzymatic method [22] with Winner ${ }^{\bullet}$ assay kits. The values are reported in milligrams per deciliter $(\mathrm{mg} / \mathrm{dL})$. The non-HDL cholesterol concentration (Non-HDL-c) was calculated as follows: non-HDL cholesterol $=$ total cholesterol - HDL cholesterol [23].

\section{Statistical analysis}

One-way analysis of variance (ANOVA) followed the Student-Newman-Keuls test was used to compare the mean values of all parameters. Differences were considered statistically significant when $p<0.05$.

\section{Results}

Glucose parameters

Glycaemia was approximately $110 \mathrm{mg} / \mathrm{dL}$ in control groups. In diabetic groups, glucose levels were greater than $400 \mathrm{mg} / \mathrm{dL}$. The $H$. speciosa aqueous extract treatment did not significantly alter hyperglycemia compared to the control group, but it decreased the glycemic level compared to the diabetic group (Fig. 1). In the OGTT test, the glycemic level was not different between the nondiabetic treated group and the control group at all time points analyzed. The diabetic non-treated animals presented increased glycemic levels at all time points compared to the control groups. The diabetic animals treated with the plant extract presented hyperglycemia at all time points of the OGTT compared to both non-diabetic animals and exhibited decreased hyperglycemia at 0, 30 and $60 \mathrm{~min}$ compared to the diabetic group. The control groups showed an area under the curve (AUC) approximately $13,000 \mathrm{mg} / \mathrm{dL} / 120 \mathrm{~min}$. The rats from the diabetic group showed a higher AUC compared than control groups, reaching approximately $60,000 \mathrm{mg} / \mathrm{dL} / 120 \mathrm{~min}$. The $H$. speciosa extract treatment did not change the AUC compared with the control group, but it reduced the AUC compared to the untreated diabetic group (Fig. 2).

\section{Indirect toxicity analyses}

No differences in body weight were observed among the experimental groups. The diabetic groups displayed

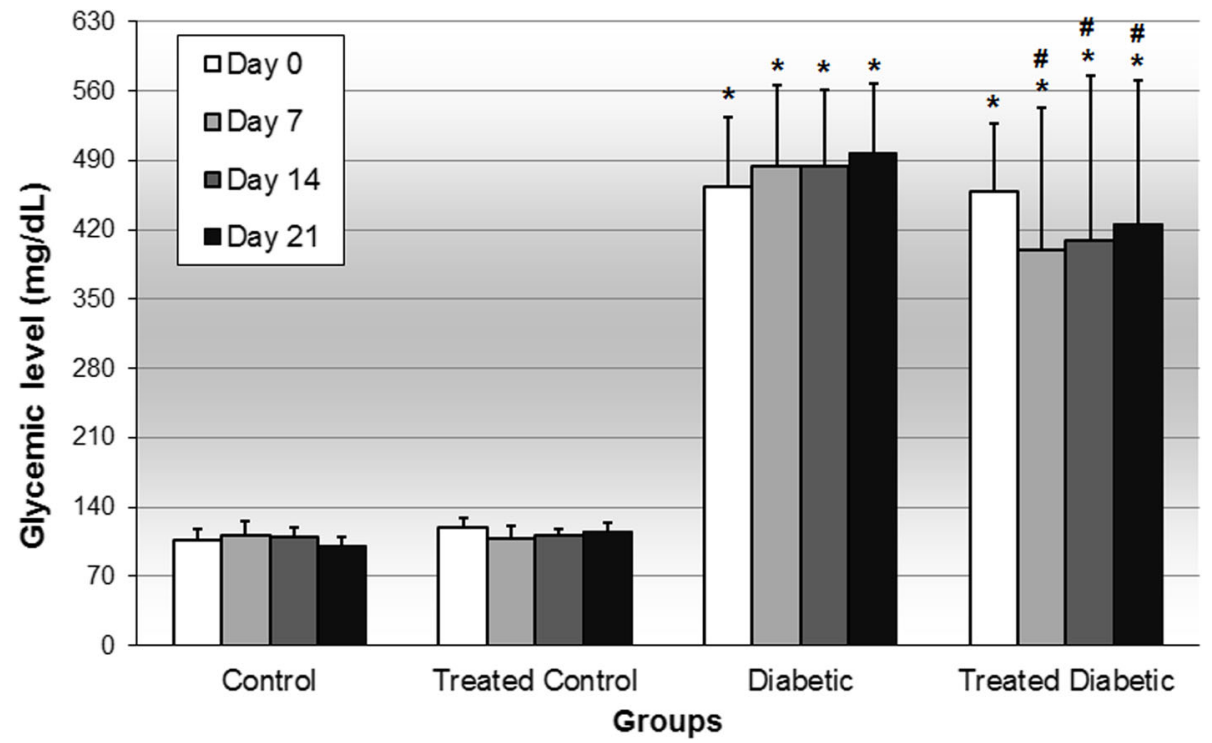

Fig. 1 Glycemic level on days 0, 7, 14 and 21 of control and diabetic rats treated or not with a Hancornia speciosa aqueous extract (400 mg/kg) during 21 days. Data are shown as mean \pm standard deviation. ${ }^{a} p<0.05$ compared with the control group (ANOVA followed Student-Newman-Keuls test). ${ }^{b} p<0.05$ compared with the diabetic group (ANOVA followed Student-Newman-Keuls test) 


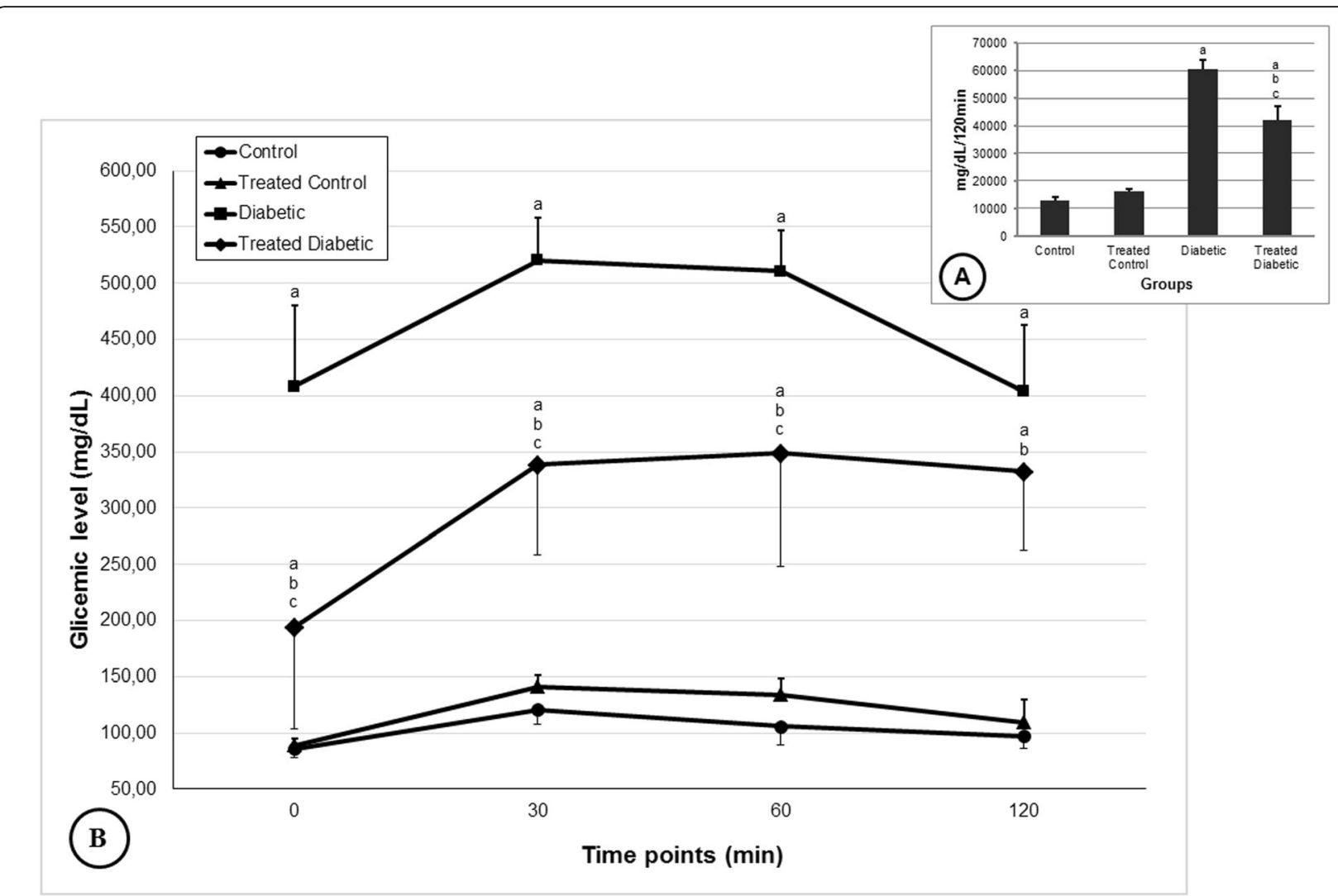

Fig. 2 Oral glucose tolerance test (OGTT) and area under the curve (AUC) at day 17 of treatment of control and diabetic rats treated or not with a Hancornia speciosa aqueous extract $(400 \mathrm{mg} / \mathrm{kg})$ during 21 days. Data are shown as mean \pm standard deviation. ${ }^{a} p<0.05$ compared with the control group (ANOVA followed Student-Newman-Keuls test) ${ }^{b} p<0.05$ compared with treated control group (ANOVA followed Student-Newman-Keuls test) ${ }^{c} p<0.05$ compared with the diabetic group (ANOVA followed Student-Newman-Keuls test)

significantly higher water intake and food consumption than the control groups. In addition, the plant treatment reduced food consumption by the diabetic animals compared to untreated diabetic animals on days 14 and 20 of the experiment (Table 1).

The diabetic group showed increased weights of all organs evaluated in this study compared with the control group. The treated diabetic group presented a reduction in the relative organ weights compared to the diabetic group, except for the relative kidney weight (Table 2).

\section{Biochemical parameters}

The diabetic group showed higher serum triglyceride, total cholesterol, and non-HDL-c levels, as well as higher ALT and AST activities than the control group. Treatment with the $H$. speciosa reduced the total cholesterol, triglyceride, and non-HDL-c levels, and ALT and AST activities in the diabetic group compared with the untreated diabetes condition (Table 3).

\section{Discussion}

Several herbal medicines are used to treat diabetes. However, some of the reported benefits have not been confirmed in laboratory experiments. Experimental models of diabetes in rats have been widely used by researchers to assess the actual hypoglycemic effect of the plants [24-26]. In this study, the diabetic groups presented hyperglycemia, indicating that streptozotocin effectively induces diabetes, consistent with the findings of other studies [25, 27-30]. The OGTT is used in the clinic to diagnose diabetes and investigate antidiabetic agents by measuring the change in plasma glucose levels in response to oral glucose administration [31].

In the present study, the Hancornia speciosa treatment $(400 \mathrm{mg} / \mathrm{kg})$ was administred to determine the plasma glucose-lowering effect. In normal animals, the treatment did not alter the plasma glucose levels or the area under the curve (AUC) during the OGTT. Nevertheless, the hyperglycemia and AUC were reduced in the rats with uncontrolled diabetes, confirming the effectiveness of the extract at reducing the blood glucose level. However, the plant did not reduce hyperglycemia to normal levels probably because of the severe diabetes status, which is characterized by severe hyperglycemia (glucose level greater than $300 \mathrm{mg} / \mathrm{kg}$ ) [32]. Pereira et al. [15] verified that the ethanolic $H$. speciosa extract $(300 \mathrm{mg} /$ 
Table 1 Body weight, water intake and food consumption of control and diabetic rats treated or not with Hancornia speciosa aqueous extract $(400 \mathrm{mg} / \mathrm{kg})$ during 21 days

\begin{tabular}{|c|c|c|c|c|}
\hline & \multicolumn{4}{|l|}{ Groups } \\
\hline & Control & Treated Control & Diabetic & Treated Diabetic \\
\hline \multicolumn{5}{|c|}{ Body weight (g) } \\
\hline Day 0 & $218.2 \pm 30.3$ & $210.6 \pm 24.7$ & $222.6 \pm 37.3$ & $211.1 \pm 16.8$ \\
\hline Day 7 & $226.4 \pm 30.0$ & $198.8 \pm 20.9$ & $217.6 \pm 30.3$ & $214.2 \pm 23.1$ \\
\hline Day 14 & $229.0 \pm 28.8$ & $211.4 \pm 23.4$ & $217.0 \pm 29.0$ & $204.1 \pm 32.4$ \\
\hline Day 20 & $230.8 \pm 28.3$ & $214.2 \pm 23.4$ & $219.8 \pm 30.6$ & $211.1 \pm 31.3$ \\
\hline \multicolumn{5}{|c|}{ Water intake $(m L)$} \\
\hline Day 0 & $35.7 \pm 8.0$ & $24.8 \pm 2.9$ & $87.1 \pm 28.0^{a}$ & $79.4 \pm 13.8^{a}$ \\
\hline Day 7 & $33.7 \pm 5.4$ & $29.6 \pm 6.1$ & $90.9 \pm 29.0^{\mathrm{a}}$ & $81.2 \pm 17.7^{\mathrm{a}}$ \\
\hline Day 14 & $36.2 \pm 5.1$ & $36.7 \pm 4.4$ & $106.0 \pm 33.4^{a}$ & $90.6 \pm 25.8^{a}$ \\
\hline Day 20 & $33.9 \pm 4.5$ & $33.2 \pm 5.7$ & $112.4 \pm 34.6^{a}$ & $102.9 \pm 20.0^{a}$ \\
\hline \multicolumn{5}{|c|}{ Food consumption (g) } \\
\hline Day 0 & $16.5 \pm 3.1$ & $13.3 \pm 3.6$ & $22.3 \pm 7.1^{\mathrm{a}}$ & $22.3 \pm 5.4^{a}$ \\
\hline Day 7 & $16.2 \pm 2.5$ & $13.6 \pm 3.4$ & $26.3 \pm 7.9^{a}$ & $23.1 \pm 4.9^{\mathrm{a}}$ \\
\hline Day 14 & $16.3 \pm 2.2$ & $17.5 \pm 3.6$ & $31.1 \pm 7.5^{\mathrm{a}}$ & $25.0 \pm 4.8^{\mathrm{ab}}$ \\
\hline Day 20 & $16.4 \pm 2.0$ & $15.5 \pm 1.8$ & $33.6 \pm 9.3^{a}$ & $23.8 \pm 7.4^{\mathrm{ab}}$ \\
\hline
\end{tabular}

Data are shown as mean \pm standard deviation (SD)

${ }^{a} p<0.05$ compared with the control group (ANOVA followed Student-Newman-Keuls test)

${ }^{b} p<0.05$ compared with the diabetic group (ANOVA followed Student-Newman-Keuls test)

$\mathrm{kg}$ ) exerted a potential anti-diabetic effect related to the inhibition of intestinal $\alpha$-glucosidase activity and stimulation of glucose uptake by adipocytes. These authors proposed that this effect might be mediated by the terpenoids, steroids and tannins present in the ethanolic $H$. speciosa extract.

The body weight loss represents a common effect of diabetes. Despite the increased appetite, insulin deficit reduces all anabolic processes and increases catabolic processes, contributing to further body weight loss [33]. This biological condition was not observed in the present study, in contrast to previous studies using this diabetic model [32, 34]. Perhaps the glycemic level, although high, was not sufficient to decrease the weight of these animals during the experimental period. Both diabetic groups showed polydipsia and hyperphagia, which were interpreted as evidence of the hyperglycemic status. These symptoms are a compensatory mechanism to deprive cells of glucose and to increase the glucose concentration in the urine [33]. However, in the present study, the treatment with plant extract decreased the food consumption on days 14 and 21 of treatment, which was probably related to the decrease in the glycemic levels of these animals. The treatment with 400 $\mathrm{mg} / \mathrm{kg}$ of the $H$ speciosa extract did not alter the food and water consumption of the non-diabetic animals, indicating that this plant does not exert an indirect toxic effect on healthy animals. The aqueous extract of $H$. speciosa leaves also showed no toxicity, as evidenced by the absence of a relevant clinical sign and the absence of deaths throughout the experimental period. The relative weights of the organs and biochemical profile also

Table 2 Relative organ weight of control and diabetic rats treated or not with Hancornia speciosa aqueous extract (400 mg/kg) during 21 days

\begin{tabular}{lllll}
\hline & Groups & & & \\
\cline { 2 - 4 } & Control & Treated Control & Diabetic & Treated Diabetic \\
\hline Heart $(\mathrm{g} / 100 \mathrm{~g})$ & $0.33 \pm 0.02$ & $0.39 \pm 0.05$ & $0.50 \pm 0.07^{\mathrm{a}}$ & $0.35 \pm 0.02^{\mathrm{a} b}$ \\
Liver $(\mathrm{g} / 100 \mathrm{~g})$ & $3.22 \pm 0.29$ & $3.36 \pm 0.23$ & $4.87 \pm 0.37^{\mathrm{a}}$ & $3.61 \pm 0.40^{\mathrm{a} \mathrm{b}}$ \\
Spleen $(\mathrm{g} / 100 \mathrm{~g})$ & $0.22 \pm 0.04$ & $0.22 \pm 0.01$ & $0.29^{\mathrm{b}} \pm 0.03^{\mathrm{a}}$ & $0.24 \pm 0.02^{\mathrm{ab}}$ \\
Right kidney (g/100 g) & $0.32 \pm 0.04$ & $0.36 \pm 0.03$ & $0.54 \pm 0.04^{\mathrm{a}}$ & $0.44 \pm 0.04^{\mathrm{ab}}$ \\
Left kidney $(\mathrm{g} / 100 \mathrm{~g})$ & $0.33 \pm 0.05$ & $0.33 \pm 0.02$ & $0.54 \pm 0.04^{\mathrm{a}}$ & $0.41 \pm 0.04^{\mathrm{ab}}$ \\
\hline
\end{tabular}

Data are shown as mean \pm standard deviation (SD)

${ }^{a} p<0.05$ compared with the control group (ANOVA followed by Student-Newman-Keuls test)

${ }^{b} p<0.05$ compared with the diabetic group (ANOVA followed by Student-Newman-Keuls test) 
Table 3 Biochemical parameters of control and diabetic rats treated or not with Hancornia speciosa aqueous extract (400 mg/kg) during 21 days

\begin{tabular}{|c|c|c|c|c|}
\hline & \multicolumn{4}{|l|}{ Groups } \\
\hline & Control & Treated Control & Diabetic & Treated Diabetic \\
\hline Total protein (g/dL) & $4.4 \pm 0.3$ & $4.5 \pm 0.3$ & $4.8 \pm 0.2$ & $4.3 \pm 0.2$ \\
\hline Tryglicerides (mg/dL) & $90.0 \pm 23.6$ & $82.4 \pm 43.0$ & $606.7 \pm 334.1^{\mathrm{a}}$ & $455.2 \pm 113.9^{a}$ \\
\hline Cholesterol (mg/dL) & $80.0 \pm 4.6$ & $75.2 \pm 18.2$ & $114.2 \pm 19.2^{a}$ & $66.1 \pm 9.2^{b}$ \\
\hline $\mathrm{HDL}-\mathrm{c}(\mathrm{mg} / \mathrm{dL})$ & $58.9 \pm 6.8$ & $49.4 \pm 7.9$ & $62.4 \pm 9.6$ & $58.3 \pm 28.6$ \\
\hline Non-HDL-c (mg/dL) & $22.3 \pm 8.8$ & $35.8 \pm 10.7$ & $52.4 \pm 21.5^{\mathrm{a}}$ & $29.6 \pm 5.7^{b}$ \\
\hline ALT (U/I) & $79.0 \pm 8.8$ & $63.2 \pm 21.9$ & $171.4 \pm 94.7^{\mathrm{a}}$ & $91.3 \pm 28.6^{b}$ \\
\hline AST (U/I) & $171.6 \pm 17.3$ & $136.2 \pm 21.6$ & $375.4 \pm 193.8^{a}$ & $159.5 \pm 37.8^{b}$ \\
\hline
\end{tabular}

Data are shown as mean \pm standard deviation (SD)

$a_{p}<0.05$ compared with the control group (ANOVA followed by Student-Newman-Keuls test)

${ }^{c} p<0.05$ compared with treated control group (ANOVA followed by Student-Newman-Keuls test)

${ }^{b} p<0.05$ compared with the diabetic group (ANOVA followed by Student-Newman-Keuls test)

represent toxicity signals [35]. In our study, the diabetic rats presented a higher relative heart weight. Hyperglycemia is a hyperosmotic state that contributes to increasing the myocardial water content, leading to heart dysfunction [36] and affecting the heart weight. In our study, the weight of the kidney (hypertrophy) was increased in diabetic groups, which might be due to local changes in the production of one or more growth factors and/or their receptors [37], glucose over-utilization and subsequent increases in glycogen synthesis, lipogenesis and protein synthesis [38]. However, treatment with the plant extract reversed the diabetic-induced damage to these organs (heart and kidneys), which was associated with decreased hyperglycemia, and consequently, reduce the relative weights of these organs.

Our findings also showed an increased relative weight of the liver in the diabetic group that as directly induced by hyperglycemia. Changes in triglyceride output by hepatocytes in diabetic animals may lead to fat accumulation in the liver, the induction of hepatic lipogenesis and an increase in intrahepatic fat synthesis [39], which might contribute to the abnormal liver weight. Diabetesinduced alterations in the liver structure lead to changes in the ALT and AST enzyme activities [40], as verified in our study. The literature confirms that hepatic enzymatic analyses have been used as signs of tissue injury and toxicity [41]. The $H$. speciosa treatment reduced ALT and AST activities, indicating the hepatoprotective effect of the plant, which also might contribute to decreasing the liver weight in these rats. Moreover, the $H$. speciosa extract decreased cholesterol levels to approximately normal values. The reduced blood cholesterol concentration might be related to the actions of some phenolic compounds present in this plant, which might inhibit 3-hydroxy-3-methylglutaryl-CoA (HMG-CoA) reductase, a rate-limiting enzyme in cholesterol biosynthesis. Similarly, other studies also suggested hypocholesterolemic effect of phenolic compound after the administration of a plant extract that was mediated by the inhibition of HMG-CoA reductase [42, 43]. H. speciosa also contains triterpenes, such as lupeol and $\alpha$ - and $\beta$-amirin [15], which potentially reduce the cholesterol levels of diabetic rats. In addition, the $H$. speciosa extract decreased triglyceride and non-HDL-c levels (represented by the lipoproteins VLDL, IDL and LDL) [23] in diabetic rats. The decrease in hyperglycemia observed after treatment with the plant extract might contribute to the mechanism regulating the hepatic gluconeogenesis and the lipid profile in the diabetic animals, decreasing glycerol and fatty acid levels, and consequently triglyceride and non-HDL-c levels, as observed in the present study.

However, limitations of this study were the utilization of only one dose during the experiment and the lack of a positive drug control, which might be included in a subsequent investigation to confirm the specific antidiabetic effect of the $H$. speciosa extract. In addition, this $H$. speciosa extract should be tested in another diabetes model presenting a lower glycemic intensity, such as less intense hyperglycemia, reproducing the level of hyperglycemia in humans with type 2 Diabetes mellitus [44].

\section{Conclusion}

In conclusion, severe diabetes is characterized by uncontrolled hyperglycemia, polydipsia, hyperphagia and dyslipidemia in rats. The aqueous extract of $H$. speciosa leaves treatment at the tested dose shows no signs of toxicity, reduces blood glucose levels and exerts lipidlowering effects. Thus, based on the findings of this investigation, the extract of $H$. speciosa potentially represents a safe and intersting candidate treatment for diabetes and other diseases.

\section{Abbreviations}

ALT: Alanine aminotransferase; ANOVA: Analysis of variance; AST: Aspartate aminotransferase; AUC: Area under the curve; CNPq: Conselho Nacional de Desenvolvimento Científico e Tecnológico; g: gram; H. speciosa: Hancornia 
speciosa; HDL-c: High-density lipoprotein; HMG-CoA: 3-hydroxy-3methylglutaryl-CoA; i.v: intravenous; L: Litter; LDL: Low-density lipoprotein; mg/dL: milligrams per deciliter; mg/kg: milligrams per kilogram; $\mathrm{mL}$ : milliliter; Non-HDL-c: Non-HDL-cholesterol; OGTT: Oral glucose tolerance test; SD: Standard deviation; STZ: Streptozotocin; UFMT: Federal University of Mato Grosso; VLDL: Very-low-density lipoprotein

\section{Acknowledgments}

The authors thank the Laboratory of System Physiology and Reproductive Toxicology and Laboratory of Experimental Research on Gynecology and Obstetrics staffs for technical assistance.

\section{Authors' contributions}

The conception and design of the study were carried out by LSN, JHC, DCD, and GTV. The data collection was performed by LSN, RQMS, TSS, MSP, TLS, and $\mathrm{JCH}$. The analysis and interpretation of data were supported by RQMS, MFA, KEC, DCD, and GTV. The drafting of the article, critical revision and final approval of the manuscript were supported by all authors.

\section{Funding}

This work was supported by Conselho Nacional de Desenvolvimento Científico e Tecnológico (CNPq)/Brazil for financial support (Process Number: 472378/2011-2 - Coordinator: GT Volpato) and financed in part by the Coordenaação de Aperfeiçoamento de Pessoal de Nível Superior - Brasil (CAPES) - Finance Code 001 (fellowship for students LS Neto, RQ MoraesSouza and TS Soares).

\section{Availability of data and materials}

The datasets used and/or analyzed during the current study are available from the corresponding author on reasonable request.

\section{Ethics approval and consent to participate}

The procedures and animal handling were performed in accordance with the guidelines provided by the Brazilian College of Animal Experimentation in agreement with the International Guiding Principles for Biomedical Research Involving Animals promulgated by the Society for the Study of Reproduction and were authorized by the Ethical Committee for Animal Research of the UFMT, Brazil (protocol number 23108.001989/13-0).

\section{Consent for publication}

Not applicable.

\section{Competing interests}

The authors declare that they have no competing interests.

Received: 16 February 2018 Accepted: 7 April 2020

Published online: 17 April 2020

\section{References}

1. Volpato GT, Moraes-Souza RQ, Soares TS, Leal-Silva T, Damasceno DC Medicinal plants for diabetes treatment during pregnancy. Curr Med Chem. 2017;24:404-10.

2. Ekor M. The growing use of herbal medicines: issues relating to adverse reactions and challenges in monitoring safety. Front Pharmacol. 2014;4:1-9.

3. World Health Organization. WHO traditional medicine strategy: 2014-2023. 2013

4. Bastos KX, Dias CN, Nascimento YM, da Silva MS, Langassner SM, Wessjohann LA, et al. Identification of phenolic compounds from Hancornia speciosa (Apocynaceae) leaves by UHPLC Orbitrap-HRMS. Molecules. 2017; 22:2-11.

5. Endringer DC, Valadares YM, Campana PR, Campos JJ, Guimarães KG, Pezzuto JM, et al. Evaluation of Brazilian plants on cancer chemoprevention targets in vitro. Phytother Res. 2010;24:928-33.

6. Pereira AB, Veríssimo TM, Oliveira MA, Araujo IA, Alves RJ, Braga FC. Development and validation of an HPLC-DAD method for quantification of bornesitol in extracts from Hancornia speciosa leaves after derivatization with p-toluenesulfonyl chloride. J Chromatogr B Analyt Technol Biomed Life Sci. 2012:887:133-7.

7. Silva GC, Braga FC, Lima MP, Pesquero JL, Lemos VS, Cortes SF. Hancornia speciosa Gomes induces hypotensive effect through inhibition of ACE and increase on NO. J Ethnopharmacol. 2011;137:709-13.
8. Cercato LM, White PA, Nampo FK, Santos MR, Camargo EA. A systematic review of medicinal plants used for weight loss in Brazil: is there potential for obesity treatment? J Ethnopharmacol. 2015;176:286-96.

9. Ferreira HC, Serra CP, Endringer DC, Lemos VS, Braga FC, Cortes SF. Endothelium-dependent vasodilation induced by Hancornia speciosa in rat superior mesenteric artery. Phytomedicine. 2007;14:473-8.

10. Ferreira HC, Serra CP, Lemos VS, Braga FC, Cortes SF. Nitric oxide-dependent vasodilatation by ethanolic extract of Hancornia speciosa via phosphatidylinositol 3-kinase. J Ethnopharmacol. 2007;109:161-4.

11. Endringer DC, Pezzuto JM, Braga FC. NF-kappaB inhibitory activity of cyclitols isolated from Hancornia speciosa. Phytomedicine. 2009;16:1064-9.

12. Silva GC, Braga FC, Lemos VS, Cortes SF. Potent antihypertensive effect of Hancornia speciosa leaves extract. Phytomedicine. 2016:23:214-9.

13. Geller FC, Teixeira MR, Pereira AB, Dourado LP, Souza DG, Braga FC, et al. Evaluation of the wound healing properties of Hancornia speciosa leaves. Phytother Res. 2015;29:1887-93.

14. Modak M, Dixit P, Londhe J, Ghaskadbi S, Devasagayam PTA. Indian herbs and herbal drugs used for the treatment of diabetes. J Clin Biochem Nutr. 2007:40:163-73.

15. Pereira AC, Pereira AB, Moreira CC, Botion LM, Lemos VS, Braga FC, et al Hancornia speciosa Gomes (Apocynaceae) as a potential anti-diabetic drug. J Ethnopharmacol. 2015;161:30-5.

16. Corvino SB, Damasceno DC, Sinzato YK, Netto AO, Macedo NCD, Zambrano $E$, et al. Comparative analysis of two different models of swimming applied to pregnant rats born small for pregnant age. An Acad Bras Cienc. 2017;89:223-30.

17. Chayarop K, Peungvicha P, Temsiririrkkul R, Wongkrajang Y, Chuakul W, Rojsanga P. Hypoglycemic activity of Mathurameha, a Thai traditional herbal formula aqueous extract, and its effect on biochemical profiles of streptozotocin-nicotinamide-induced diabetic rats. BMC Complement Altern Med. 2017;17:4-11.

18. Mello MAR, Souza T, Braga LR, Santos W, Ribeiro IA, Gobatto CA. Glucose tolerance and insulin action in monosodium glutamate (MSG) obese exercise-trained rats. Physiol Chem Phys Med. 2001;33:63-71.

19. Sinzato YK, Volpato GT, lessi IL, Bueno A, Calderon Ide M, Rudge MV, et al. Neonatally induced mild diabetes in rats and its effect on maternal, placental, and fetal parameters. Exp Diabetes Res. 2012;2012:1-8.

20. Tai MM. A mathematical model for the determination of total area under glucose tolerance and other metabolic curves. Diabetes Care. 1994;17:152-4.

21. Gornall AG, Bardawill CJ, David MM. Determination of serum proteins by means of the biuret reaction. J Biol Chem. 1949:177:751-66.

22. Young DS. Effects of drugs on clinical laboratory tests. Washington DC: AACC Press; 2000

23. Yu S, Wu X, Ferguson M, Simmen RCM, Cleves MA, Simmen FA. Diets containing shiitake mushroom reduce serum lipids and serum lipophilic antioxidant capacity in rats. J Nutr. 2016;146(12):2491-6.

24. Junod A, Lambert AE, Stauffacher W, Renold AE. Diabetogenic action of streptozotocin: relationship of dose to metabolic response. J Clin Invest. 1969;48:2129-39.

25. Volpato GT, Calderon IMP, Sinzato S, Campos KE, Rudge MV, Damasceno DC. Effect of Morus nigra aqueous extract treatment on the maternal-fetal outcome, oxidative stress status and lipid profile of streptozotocin-induced diabetic rats. J Ethnopharmacol. 2011;138:691-6.

26. Afiune LAF, Leal-Silva T, Sinzato YK, Moraes-Souza RQ, Soares TS, Campos $K E$, et al. Beneficial effects of Hibiscus rosa-sinensis $L$. flower aqueous extract in pregnant rats with diabetes. PLoS One. 2017;12:1-13.

27. Eriksson UJ, Cederberg J, Wentzel P. Congenital malformations in offspring of diabetic mothers - animal and human studies. Rev Endocr Metab Disord. 2003:4:79-93.

28. Damasceno DC, Sinzato YK, Lima PH, de Souza MS, Campos KE, Dallaqua B, Calderon IM, Rudge MV, et al. Effects of exposure to cigarette smoke prior to pregnancy in diabetic rats. Diabetol Metab Syndr. 2011;3:1-20.

29. Damasceno DC, Silva HP, Vaz GF, Vasques-Silva FA, Calderon IM, Rudge MV et al. Diabetic rats exercised prior to and during pregnancy: maternal reproductive outcome, biochemical profile, and frequency of fetal anomalies. Reprod Sci. 2013;20:730-8

30. Volpato GT, Damasceno DC, Sinzato YK, Ribeiro VM, Rudge MV, Calderon IM Oxidative stress status and placental implications in diabetic rats undergoing swimming exercise after embryonic implantation. Reprod Sci. 2015;22:602-8 
31. Krisanapun C, Peungvicha P, Temsiririrkkul R, Wongkrajang Y. Aqueous extract of Abutilon indicum sweet inhibits glucose absorption and stimulates insulin secretion in rodents. Nutr Res. 2009;29:579-87.

32. Pinheiro MS, Rodrigues LS, Neto LS, Moraes-Souza RQ, Soares TS, Américo MF, et al. Effect of Bauhinia holophylla treatment in Streptozotocin-induced diabetic rats. An Acad Bras Cienc. 2017;89:263-72.

33. Kahn CR, Weir GC, King GL, Jacobson AM, Moses AC, Smith RJ. Joslin's Diabetes mellitus. New York: Lippincott Williams \& Wilkins; 2005.

34. Doğan A, Çelik I. Healing effects of sumac (Rhus coriaria) in streptozotocininduced diabetic rats. Pharm Biol. 2016;54:2092-192.

35. Ateba SB, Simo RV, Mbanya JC, Krenn L, Njamen D. Safety profile and gender-specific differences of a methanol extract of Eriosema laurentii (Leguminosae) in acute and subchronic (28 days) oral toxicity studies in Wistar rats. Food Chem Toxicol. 2014;65:27-32.

36. Koltai SM, Kocsis E, Pósa I, Hadházy P, Jermendy G, Pogátsa G. The diabetic heart: a review of the lifework of Sophie Maria Koltai. Exp Clin Cardiol. 2002; 7:205-11.

37. Zafar M, Naqvi SNH. Effects of STZ-induced diabetes on the relative weights of kidney, liver and pancreas in albino rats: a comparative study. Int J Morphol. 2010;28:135-42.

38. Malatiali S, Francis I, Barac-Nieto M. Phlorizin prevents glomerular hyperfiltration but not hypertrophy in diabetic rats. Exp Diabetes Res. 2008; 2008:1-7.

39. Regnell SE, Lernmark Å. Hepatic steatosis in type 1 diabetes. Rev Diabet Stud. 2011;8:454-67.

40. Zafar M, Naqvi SNH, Ahmed M, Kaimkhani ZA. Altered liver morphology and enzymes in streptozotocin-induced diabetic rats. Int J Morphol. 2009;27: 719-25.

41. Adegoke AM, Gbadegesin MA, Odunola OA. Methanol extract of Adansonia digitata leaf protects against sodium arsenite-induced toxicities in male Wistar rats. Pharm Res. 2017:9:7-11.

42. Belguith-Hadriche O, Bouaziz M, Jamoussi K, El Feki A, Sayadi S, Makni-Ayedi F. Lipid-lowering and antioxidant effects of an ethyl acetate extract of fenugreek seeds in high-cholesterol-fed rats. J Agric Food Chem. 2010;58: 2116-22.

43. Oshaghi EA, Khodadadi I, Saidijam M, Yadegarazari R, Shabab R, Tavilani H, et al. Lipid-lowering effects of hydroalcoholic extract of Anethum graveolens $L$ and dill tablet in high cholesterol-fed hamsters. Cholesterol. 2015;2015:1-7.

44. Damasceno DC, Sinzato YK, Bueno A, Netto AO, Dallaqua B, Gallego FO et al. Mild diabetes models and their maternal-fetal repercussions. J Diabetes Res. 2013;2013:1-9.

\section{Publisher's Note}

Springer Nature remains neutral with regard to jurisdictional claims in published maps and institutional affiliations.

Ready to submit your research? Choose BMC and benefit from:

- fast, convenient online submission

- thorough peer review by experienced researchers in your field

- rapid publication on acceptance

- support for research data, including large and complex data types

- gold Open Access which fosters wider collaboration and increased citations

- maximum visibility for your research: over $100 \mathrm{M}$ website views per year

At $\mathrm{BMC}$, research is always in progress.

Learn more biomedcentral.com/submissions 